УДК 69.059:622.23.05

(C) 2014

Прасолов С. Я., кандидат технічних наук,

Лапенко Т. Г., кандидат технічних наук, Бондаренко О. Ю., студент

Полтавська державна аграрна академія

\title{
ПІДВИЩЕННЯ СТІЙКОСТІ ДЕТАЛЕЙ ПРОТИ ЗНОШУВАННЯ ДВИГУНІВ СІЛЬСЬКОГОСПОДАРСЬКОЇ ТЕХНІКИ
}

\section{Рецензент - доктор технічних наук В. П. Дмитриков}

Підвищення стійкості деталей проти зношування двигунів сільськогосподарської техніки обтрунтована необхідністю покриття поверхонь спряжених деталей неорганічними, неметалевими, фосфатними плівками. Підібрано та обгрунтовано технологічний проиес, умови підготовки вихідних матеріалів та склад робочого розчину за визначеної температури. Встановлено за результатами досліджень залежності: температури робочого розчину від концентрації; лінійної швидкості в контрольних точках від величини зношення поверхні зразків. Запропоновані рекомендації щзодо реалізащії технологї нанесення антифрикиійного покриття у виробництві. Технологічний проиес нанесення конверсійних покриттів із насиченням їх наноматеріалами апробований для виготовлення деталей тертя двигунів сільськогосподарської техніки і має достатню комериійну привабливість.

Ключові слова: зносостійкість, фосфатування, припрачювання, конверсійне покриття, наноматеріали, антифрикиійність.

Постановка проблеми. Вітчизняні та деякі імпортні двигуни сільськогосподарської техніки експлуатуються в умовах не зовсім якісного проведення технічного обслуговування і ремонту у зв'язку або недостатньою забезпеченістю технологічним обладнанням сервісних служб за умов екстремальних виробничих факторів. Одним із джерел підвищення довговічності й технологічної готовності двигунів - це якісний ремонт та сервіс. Для підвищення довговічності та надійності двигунів потрібне застосування новітніх наукових досягнень у галузі технологій ремонту.

Підвищення стійкості деталей проти зношування - це один із актуальних напрямів під час вирішення питань підвищення ресурсу двигунів у цілому. Це досягається зміцненням спряжень та забезпеченням умов роботи, за яких зменшується коефіцієнт тертя і під час надання відновлення поверхням деталей спеціальних властивостей зменшується питома витрата палива та підвищується довговічність двигунів.

Деталі циліндро-поршневої групи обмежують ресурс двигуна і визначальним для підвищення надійності та ресурсу $є$ нанесення теплозахисних, антипригарних та антизадирних покриттів. Досвід зарубіжних країн протягом останніх років показує доцільність такої обробки, що збільшує ресурс циліндро-поршневої групи майже у два рази. Подовження терміну служби машин i устаткування рівноцінно введенню значних нових виробничих потужностей.

Розробка, виробництво й експлуатація двигунів постійно супроводжуються пошуком шляхів підвищення ККД, зниження витрат, використання доступних і дешевих матеріалів, полегшення, прискорення і підвищення гнучкості ремонту.

Нині застосовуються методи нанесення покриттів на поверхню деталей: тонких шарів напилення, полімерних плівок, гальванічних шарів, композитних плівок. Із відомих способів нанесення неметалевих, неорганічних покриттів особливий інтерес викликає фосфатування. Виходячи 3 умов найменших витрат на проведення процесу нанесення покриттів, властивості зменшувати коефіцієнт тертя, дослідження доцільно проводити в напрямі використання методу нанесення та просочування нанесених фосфатних покриттів різними розчинами.

Аналіз останніх досліджень і публікацій, у яких започатковано розв'язання проблеми. Зі збільшенням робочих швидкостей, тиску, температур, агресивності середовища, жорсткіші умови, які характерні для роботи сучасного виробництва, збільшується й інтенсивність зношування; корозія поверхні металу деталей знаходяться в спряженні між собою.

Експлуатаційні властивості деталей двигунів визначаються станом поверхневого шару. Проблема електрохімічного стану поверхневого шару сталей у разі механічної дії залишається актуальною, оскільки від неї залежить якість поверхні, що утворюється. В роботах [1-5] висвітлено вплив аніонного складу середовища на пасивування заліза під час спряження поверхонь деталей. 


\section{TEХНIЧНІ НАУКИ}

Фосфатні покриття відомі як сповільнювачі корозій вторинної дії [1-2], тобто вони застосовуються як інгібітори корозії [3-6]. За мінімальної концентрації фосфатів створюється оптимальний захист металу, що слід віднести до переваг перед іншими інгібіторами [6-8]. Фосфатна плівка на поверхні спряжених деталей змінює кінетику електрохімічних реакцій. Недоліком фосфатування $\epsilon$ утруднення процесу покриття складної форми деталей.

Мета та завдання досліджень. Мета - це підвищення довговічності (ресурсу) деталей двигуна шляхом визначення впливу складу та концентрації розчину на антифракційні властивості фосфатних поверхонь.

Завдання: обрати матеріали для фосфатування поверхонь деталей. Виконати експериментальні дослідження 3 нанесення фосфатних покриттів різної концентрації. Провести дослідження 3 просочування нанесення фосфатних покриттів та порівняльні випробування на зносостійкість поверхонь спряжених деталей.

Матеріали і методика досліджень. Виготовлення зразків і проведення дослідів проводилося разом $з$ працівниками в лабораторіях ННЦ «IMECT».

Під час вибору матеріалу для нанесення фосфатних покриттів виходили з умов найменших витрат та досягнення необхідних показників по адгезії, коефіцієнту тертя.

Для одержання фосфатних плівок використовуються кислотні, лужні та сольові розчини. На якість фосфатних плівок впливають загальна та довільна кислотності розчину, його склад і робоча температура.

Тривалість процесу також впливає на товщину і пористість нанесення матеріалів. Робочий розчин готували методом розчинення зваженої кількості сухої речовини, з наступним нагріванням до кипіння. Після випадання осаду та охолодження до $60-70{ }^{\circ} \mathrm{C}$ розчин доводили до температури $96-98^{\circ} \mathrm{C}$ і він був готовий до використання.

Досконалі захисні плівки одержують із розчину «Мажеф» концентрацією 30-35 г/л, при температурі 96-98 ${ }^{\circ} \mathrm{C}$ за 80-90 хвилин. Підвищення концентрацій розчину до 100-200 г/л сприяє зменшенню коефіцієнту тертя. 3 розчинів солей «Мажеф» отримують плівки 7-50 мкм, що мають значну міцність зчеплення зі сталлю й якісну мікропористу структуру, яка добре вбирає лаки, фарби та змащуючі речовини.

Для досліджень вибрано сольовий концентрат ФК-16. Режими нанесення покриттів і витрати матеріалів та часу для покриття підтверджують перевагу концентрату ФК-16. Розчин вміщує збільшену кількість марганцю, що дає змогу отримати більш стійку до зношування поверхню. Приготування розчинів заданої концентрації проводилися відважуванням потрібної кількості концентрату та розчиненням у розрахунковій кількості води. Для досліджень виготовляли зразки зі сталі Ст. 3 з прямокутним профілем перерізу. Зразки маркувались, зовнішні поверхні шліфували, знежирювали в органічному розчиннику та наносили шари покриття при температурі $95 \pm 5{ }^{0} \mathrm{C}$ протягом 45 хвилин. Зразки промивали в проточній воді, висушували за $\mathrm{t}=100{ }^{\circ} \mathrm{C}$ впродовж 30 хвилин.

Результати досліджень. Випробовувалися зразки зі сталі Ст. 3 без покриття, 3 нанесеним шаром i просоченим мастилом М10Г2К та М10Г2К із додаванням протизношувальних добавок. Під час виконання досліджень використовувались прилади, які пройшли метрологічну повірку. Зразки покривались фосфатним шаром.

3 десяти зразків шість отримали рівномірні щільні шари темного кольору, на сьомому і восьмому зразках поверхні були не досить якісними, а на дев'ятому й десятому зразках нанесені шари на поверхні змивалися водою під час промивання.

Поверхні зразків досліджувались під мікроскопом (×400). Основна маса фосфатного шару утворюється в перші хвилини процесу.

Для зразків із маркуванням 7, 8, 9, 10 експериментальним шляхом встановили раціональні режими нанесення фосфатного шару.

Графічна залежність температури від концентрації робочого розчину представлена на рисунку 1. Зразки 3 нанесеним фосфатним покриттям піддавалися стиранню при навантаженні 0,04 МПа за тривалості 5 хв та частоті $10 \mathrm{c}^{-1}$ обертання контртіла у вигляді диску.

Шлях стирання оцінювався довжиною від 4525 м до 5285 м за зміни швидкості стирання від 2,4 до $2,8 \mathrm{~m} / \mathrm{c}$.

На рисунку 2 представлена гістограма значень діаметра лунки до випробувань.

Розгляд слідів та величин зношень поверхні зразка вказує на поліпшення антифрикційних властивостей у сторону збільшення концентрації робочого розчину до 125 г/л включно. Властивості поверхні, починаючи 3140 г/л, погіршуються. Якість поверхні найгірше у першого зразка і найкраща в сьомого. Залежність зношення поверхонь зразків представлена на гістограмі (рис. 3). 


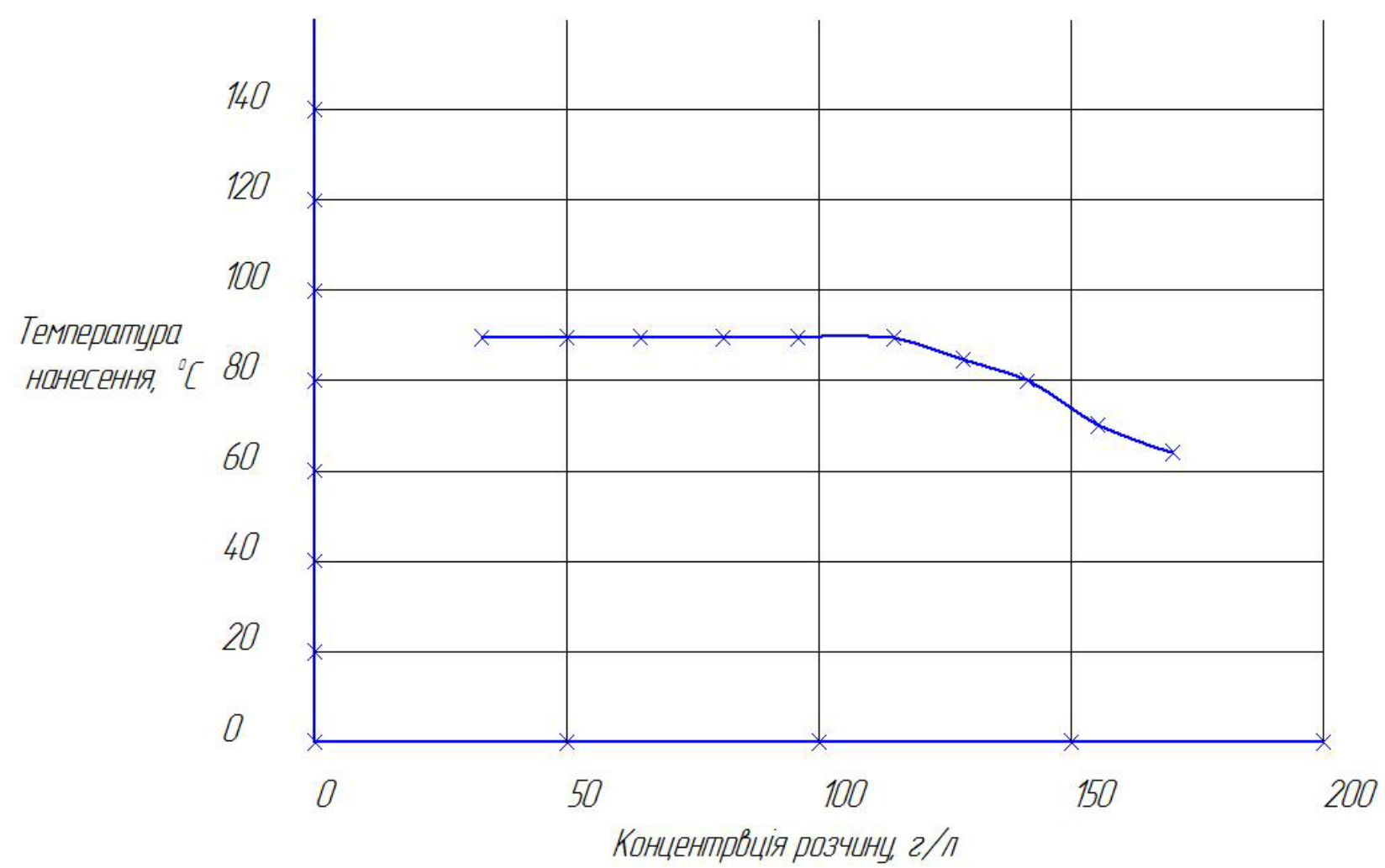

Рис. 1. Залежність температури робочого розчину від концентрації

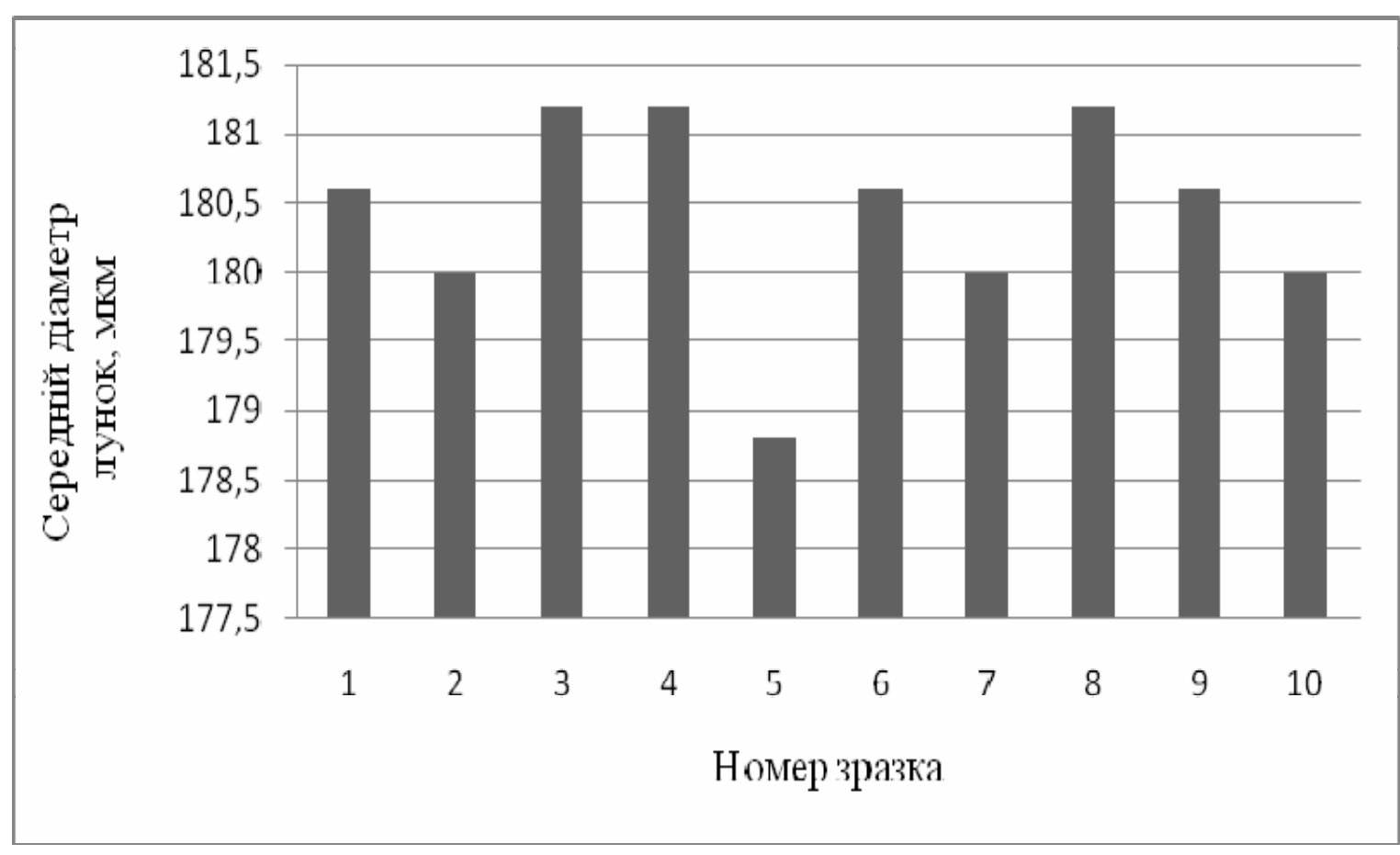

Рис. 2. Середнє значення діаметра з першої по п'яту лунку в залежності від номера зразка 


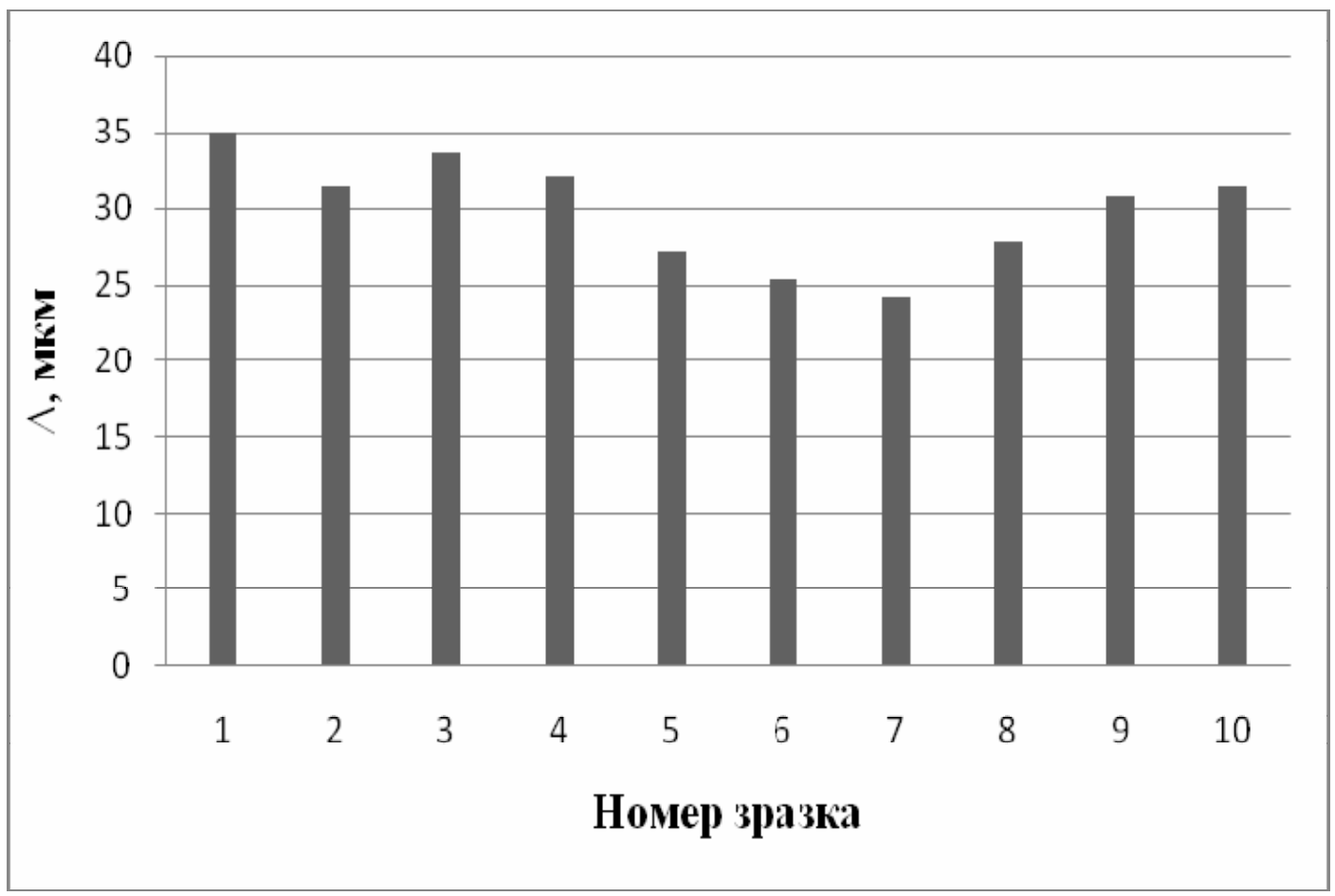

Рис. 3. Гістограма залежності зношення поверхні від номера зразка

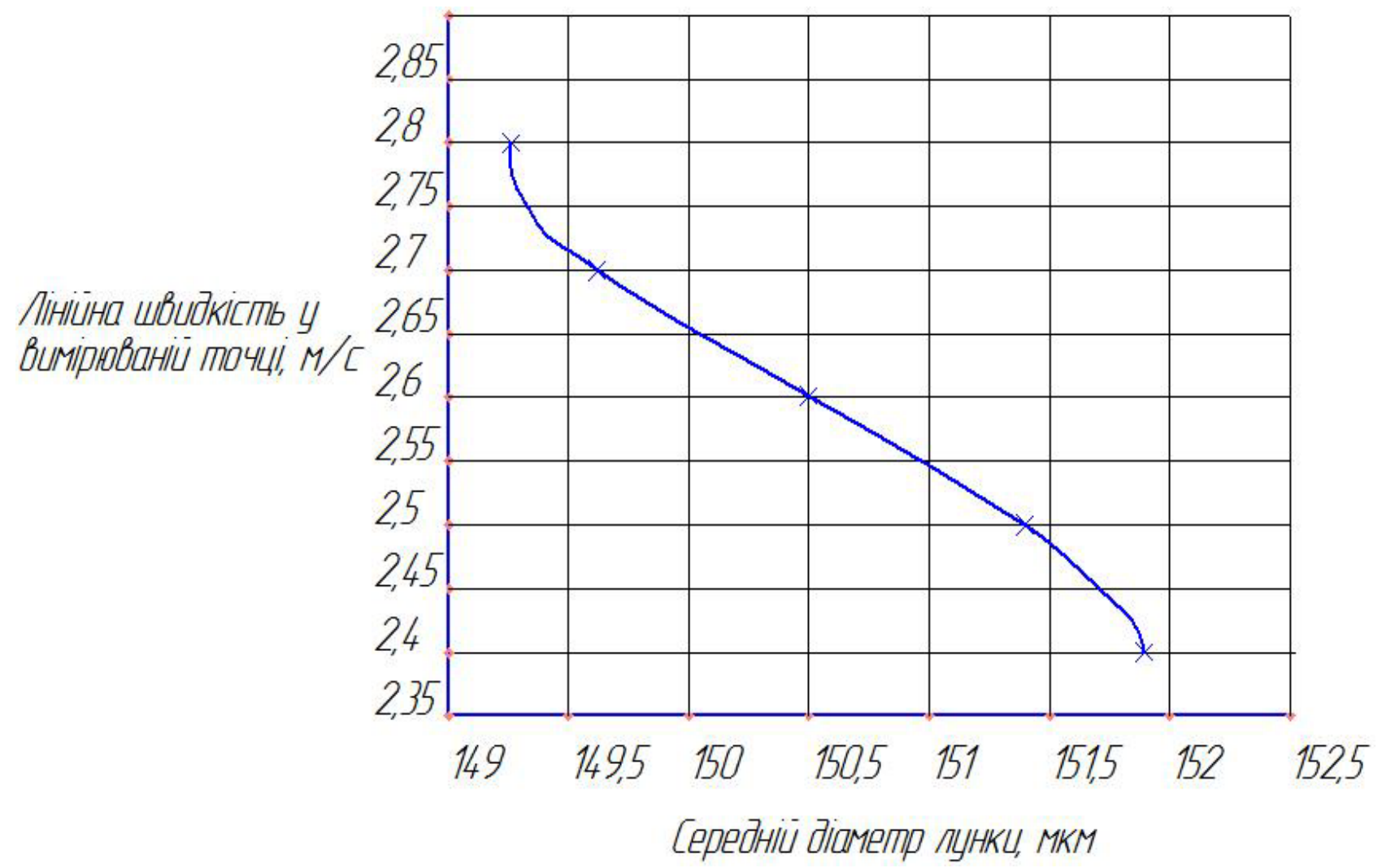

Рис. 4. Залежність лінійної ивидкості в контрольних точках від зношення поверхні зразків 
Залежність лінійної швидкості в контрольних точках від зношення поверхонь зразків представлена на рисунку 4.

3 графіка (рис. 4) помітно, що більшому зношенню відповідає більша швидкість зношування. За результатами проведених досліджень встановлені оптимальні режими нанесення покриттів: концентрація робочого розчину - 125 г/л, температура $85^{\circ} \mathrm{C}$, час нанесення - 45 хвилин. За вказаними режимами отримували найвищу зносостійкість поверхонь зразків. Наступні дослідження зносостійкості фосфатних покриттів, просочених антифрикційними розчинами, проводилися при навантаженні 0,04 МПа, частоті обертання контртіла диска $10 \mathrm{c}^{-1}$ та за тривалості досліду $60,120,180$ хвилин. Результати досліджень представлені у вигляді гістограм.

На гістограмах (рис. 5 , рис. 6 , рис. 7) представлені результати змін діаметра лунок, відповідно після 60 хв, 120 хв і 180 хвилин.

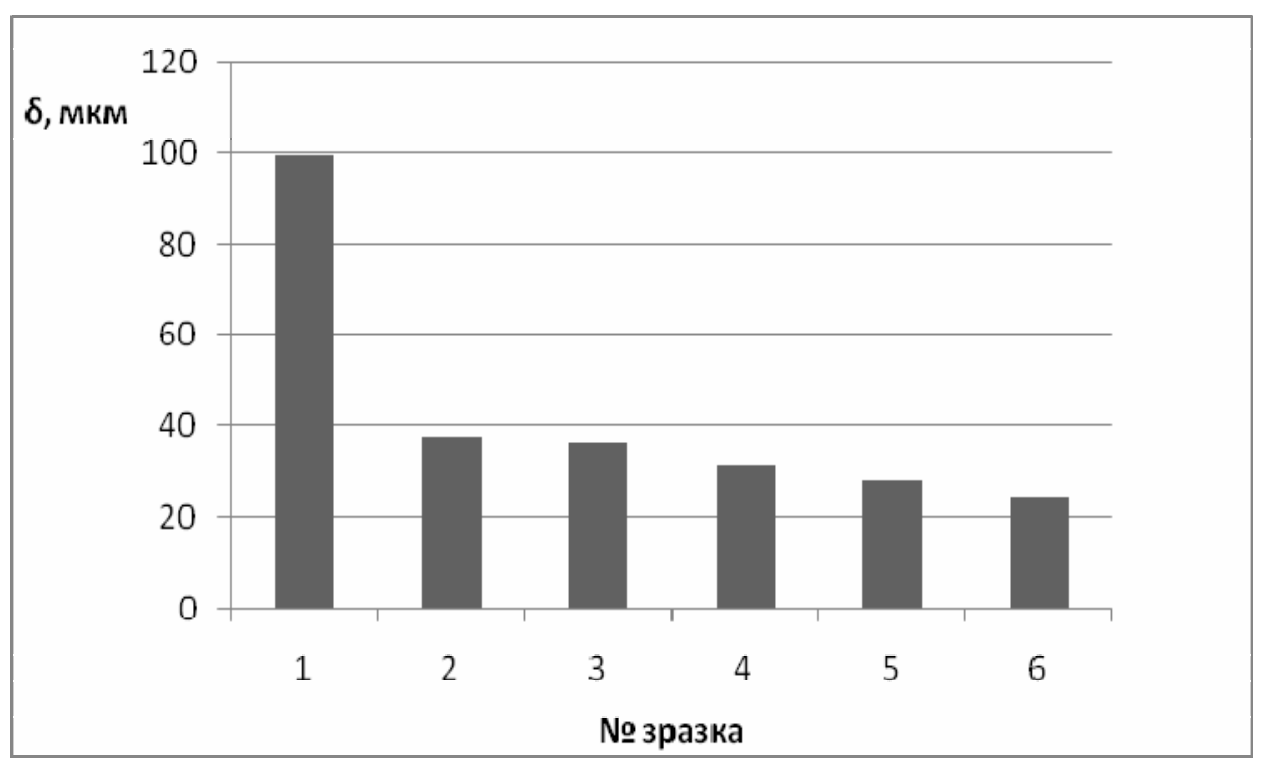

Рис. 5. Гістограма зміни діаметра лунок після 60 хв тертя

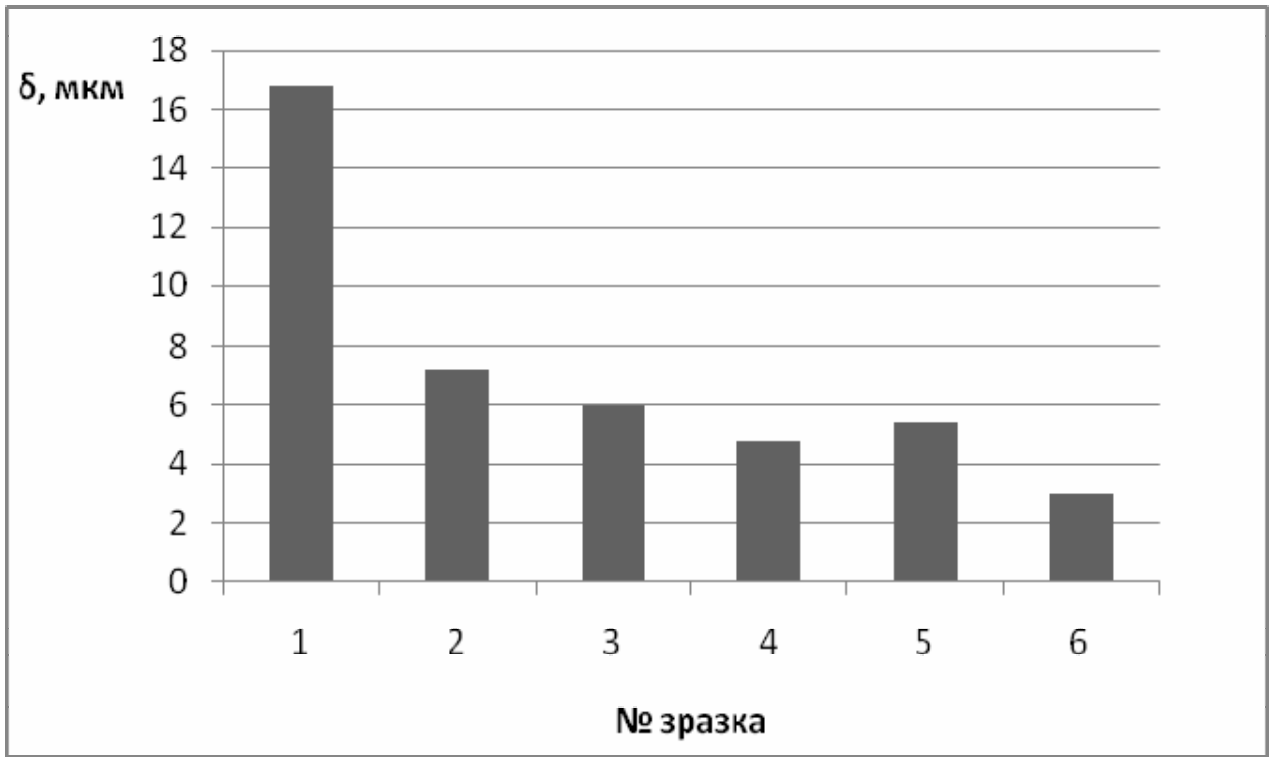

Рис. 6. Гістограма зміни діаметра лунок після 120 хв тертя 


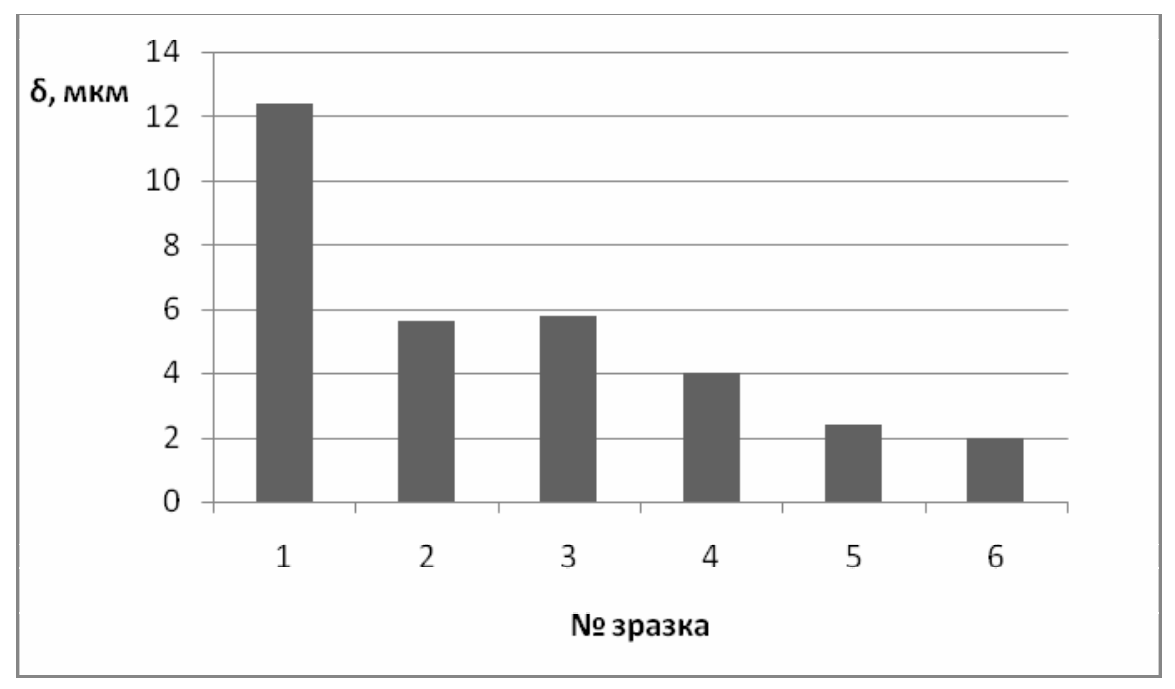

Рис. 7. Гістограма зміни діаметра лунок після 180 хв тертя

2. MKM 140

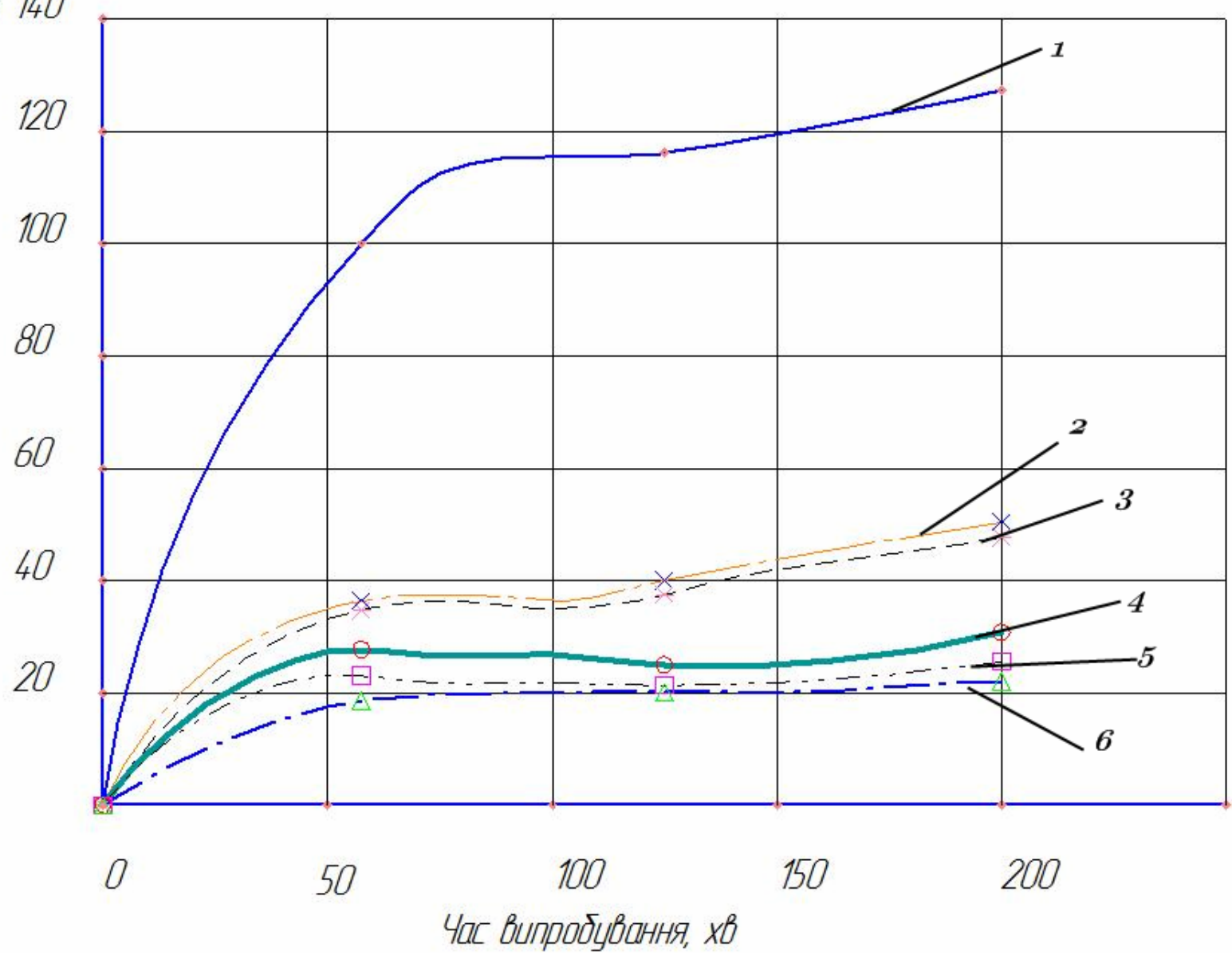

Рис. 8. Залежність зношування поверхонь зразків з урахуванням часу досліджень

За перші години випробувань добавки позитивно вплинули на процес припрацювання, що бачимо по шостому зразку.

Зміна середнього діаметра п'яти контрольних точок зразка склали приблизно 24 мкм. У порів- нянні $з$ першим зразком, який без фосфатного покриття, різниця зношування склала 75 мкм.

Протягом наступної години випробувань зношування першого зразка склала приблизно 17 мкм, а зразків просочених антифрикційними 


\section{ТЕХНІЧНІ НАУКИ}

матеріалами коливалася в межах $3 \approx 7$ мкм.

За третьої години випробувань п'ятий і шостий зразки мають найменше зношування.

На рисунку 8 представлена залежність зношування поверхонь зразків з урахуванням часу.

Аналіз характеру кривих зношень поверхонь зразків показав, що добавка гель-ревіталізант «Хондо» дала стабільний ефект після періоду припрацювання поверхні зразка. Добавки $\mathrm{Al}_{2} \mathrm{O}_{3}$ також збільшують антифрикційність.

Під час порівняння результатів досліджень бачимо, що зразки просочені технічним парафіном і чистою оливою, проте помітної величини зношення не спостерігається.

Характер кривих свідчить, що припрацювання поверхні й зношення в наступні дві години має найменші величини - 3 і 2 мкм відповідно.

У цілому добавки, що додавалися до просочувального розчину, позитивно вплинули на антифрикційні властивості фосфорного покриття.

Висновки: 1. Встановлено, що підвищення зносостійкості поверхонь деталей спряження в

\section{БІБЛІОГРАФІЯ}

1. Гаркунов Д. М. Триботехника / Д. М. Гаркунов. М. : Машиностроение, 1985. - 424 с.

2. Журавльова Л. О., Колодяжна Л. Г., Покінтелиия М. Я. Фосфатування поверхні вуглецевих сплавів в процесі вібраційної механохімічної обробки / Л. О. Журавльова, Л. Г. Колодяжна, М. Я. Покінтелиця // Вісник Вінницького політехнічного інституту машинобудування і трактоpiв. - 2008. - № 4. - С. 89-91.

3. Износостойкость сплавов, восстановление и упрочнение деталей машин [учебное пособие / под общей ред. В. С. Попова]. - Запорожье : ОАО «Мотор Сич», 2006. - 420 с.

4. Коновалова $B$. C. Оптимизация процесса химического фосфатирования стали [текст] / двигунах сільськогосподарської техніки досягається шляхом нанесення фосфорної плівки.

2. Підібрано та обгрунтовано технологічний процес, умови підготовки вихідних матеріалів i склад робочого розчину під час визначення температури.

3. Встановлені за результатами дослідження залежності температури робочого розчину від концентрації, лінійної швидкості в контрольних точках від величини зношення поверхні зразків.

4. Результати лабораторних досліджень були підтверджені у виробничих умовах для виготовлення спряжених деталей тертя двигунів сільськогосподарської техніки i мають комерційну привабливість.

У подальшому планується провести дослідження по створенню та вдосконаленню способів отримання поверхневих плівок 3 нанофазними структурами, які складаються із композицій металів, сплавів, неметалевих матеріалів і органічних сполук.

В. С. Коновалова, К. Е. Румянцева, В. Е. Румянцева // Сборник тезисов докладов 9-й международной конференции [«Покрытия и обработка поверхности»]. - М., 2012. - С. 64-65.

5. Розенфельд И. Л. Коррозия и защита методов / И. Л. Розенфельд. - М., 1970. - 448 с.

6. Томамов А. Д. Лабораторные работы по коррозии и защите металлов [текст] / [Н. Д. Томашов, Н. П. Жрук, В. А. Титов, М. А. Веденеева]. - М. : Металлургия, 1971. - 140 с.

7. Adams A. A., Foby R. T. Corrosion / A. A. Adams, R. T. Foby. $-1975-$ V. 31. -84 p.

8. Ratzer - Sehibe N. I. Werkst. Anol Korros / N. I.Ratzer - Sehibe. - 1975. - V. 26. - P. 2-10. 